\title{
An Overview of Social Studies Articles in Turkey: Bibliometric Mapping Analysis
}

\author{
Yavuz Sökmen* \\ Received: July 3, 2020; received in revised form: August 28, 2020; \\ accepted: September 2, 2020
}

\begin{abstract}
:
Introduction: This research applies a bibliometric analysis to articles that have been published in Turkey in the field of social studies. "Social studies" is a discipline that aims to develop a human model with certain features applicable both for researchers' own countries and globally. In this context, individuals' social, work, and domestic lives are considered fundamental. Thus, discovering the characteristics of studies on social studies could be useful to interested scholars or policy-makers for determining trends in the field.

Methods: In this context, 168 articles from the Web of Science database were analyzed in bibliometric terms. Here, the keywords "social studies teaching," or "social studies," or "social studies education" were used when searching the Web of Science database, and Turkey was selected as the study location.

Results: Results of the bibliometric analysis showed that the most productive universities in Turkey are Anadolu, Marmara, and Gazi Universities, and the most frequently used keywords on the topic are "social studies," "social studies education," and "citizenship education." Moreover, the most-used words in the manuscripts" abstracts are "level," "Turkey," "participant," and "impact." The most-cited authors (judged using co-citation analyses) are Yıldırım, Öztürk, and Creswell, and the most-cited journals (judged using co-citation analyses) are The Social Studies, Journal of Educational Psychology, and Eğitim ve Bilim.

Discussion: When the articles in the field of social studies were analyzed by years, it was seen that the first one is published in 2007 and citations have occurred since 2009. It can be understood from the research results that words such as academic success, motivation and social justice keywords also have been recently used. It is understood that most of the journals are not specific to social studies and are general educational journals.
\end{abstract}

\footnotetext{
* Yavuz Sökmen, Atatürk University, Kazım Karabekir Education Faculty, Turkey; yavuzsokmen@atauni.edu.tr
} 


\title{
Acta Educationis Generalis \\ Volume 11, 2021, Issue 2
}

\begin{abstract}
Limitations: The only articles examined within the scope of the study were those found in the Web of Science database. This can be considered a limitation of this research.

Conclusion: Considering that the most-cited authors, according to the results of the study, are included in the bibliographies of the studies related to this field, examining their works may be a useful guide for interested scholars. The majority of the journals included in the study were general education journals. It was also noted that the majority of the most-cited journals were based in Turkey.
\end{abstract}

Key words: social studies, bibliometric analysis, Turkey.

\section{Introduction}

The concept of "social studies" was first developed during the 19th century in the United States (Doğanay, 2008). "The primary purpose of social studies is to help young people develop the ability to make knowledgeable and rational decisions as citizens of democratic societies with cultural diversity in a mutualist world." (National Council for the Social Studies [NCSS], 2018) In this context, social studies are fundamental for raising knowledgeable citizens, who are a necessity for societies (Türk \& Nalçacı, 2011; Yaşar et al., 2015). In addition, preparing children to realize their roles as citizens of the world and integrating the whole program into it are among the essential goals of social studies curricula (Seefeldt et al., 2014). Öztürk (2009) notes that the main purpose of social studies is to raise efficient citizens who can solve problems and make information-based decisions about the changing standards of their country and the world.

Social studies teaching is important for all students, so they can understand how their roles, rights, responsibilities, and actions as a citizen can affect their society (Garwood et al., 2019). Social studies courses examine people and their interactions with the environments in which they belong, in terms of time and place (Doğanay, 2008). The first social studies course was taught in the United States (Görmez, 2018). Today, social studies is one of the basic courses of primary education programs around the world (Deveci, 2005); likewise, it is an essential part of the Turkish education system (Akpınar \& Kaymakcı, 2012). Social studies was included in the Turkish curriculum for the first time in 1968 (Tay \& Akyürek-Tay, 2006). Öztürk (2009) defines the social studies course as "a curriculum that uses information and methods from the social studies and humanities coherently to raise efficient citizens who can make informationbased decisions and solve problems in a transforming country and world". At the same time, social studies courses not only play an important role in helping students to acquire the characteristics needed to be successful in their civic lives (Eryılmaz \& Çengelci-Köse, 2018), they also aim to endow students with 
reasoning and creativity skills, and to provide solutions to social and personal problems (Ay-Selanik \& Deveci, 2016).

When the Turkish social studies literature is examined, various content analyses studies emerge. Dilek et al. (2018) conducted a content analysis of master's theses in social studies education written between 2010 and 2017. Tarman et al. (2010) examined master's theses and doctoral dissertations in the same field written between 1994 and 2010. Their analysis found that qualitative research methods are preferred in master's theses, while qualitative, quantitative, and mixed methods approaches were the most preferred research methods in doctoral dissertations. Teachers were the most preferred individuals for the studies' sample groups. Oruç and Ulusoy (2008) argued that the theses on social studies teaching have problems and shortcomings because their research methods tend to be difficult to discern thoroughly and properly. The literature indicated that there are many eclectic, meta-synthesis and meta-analysis studies related to social studies apart from these (Güleç \& Hüdavendigar, 2020; Şahin et al., 2011; Yaşar et al., 2015) that provide various pieces of information about the scholars in this field. This study, which covers articles in the Web of Science database published between 2007 and 2020, aims to introduce a different perspective on social studies by including a simultaneous bibliometric analysis.

Given the context outlined above, the study includes a simultaneous bibliometric analysis of articles about social studies. This overall analysis should prove useful for interested scholars working in the field of social studies and social studies education. This study aims to determine the annual distribution of the number of publications and citations, the universities with the most published articles, the most-used keywords, the most-used words in the articles' abstracts, the mostcited authors, and the distribution of the most-cited journals.

\section{Method}

\subsection{Data collection}

Analyses of the articles included in the study were conducted according to bibliometric analysis. In this context, information about the methods followed for the analyses is explained.

\subsection{Bibliometric analysis}

Articles analyzed within the scope of the study for bibliometric analysis were obtained on March 26, 2020 through the Web of Science database. The articles were taken from the Web of Science database since it is both widely used and accepted in the scientific world (Gürlen et al., 2018) and it is a high-quality database that includes SSCI, SCI-EXPANDED, A\&HCI, CPCI-S, CPCI-SSH, and ESCI indices (Shen \& Ho, 2020). In this direction, the keywords "social studies teaching", "social studies" and "social studies education" were used in the Web of Science database and Turkey was selected for the location option. In 
addition, only the article button was selected for the filtration options. Moreover, education category was selected for the articles that were obtained from the search results. Through this search, 168 articles published between 2007 and 2020 were acquired for the bibliometric analysis.

VOSviewer software program developed by Van Eck and Waltman (2010) was utilized for bibliometric analysis of the articles obtained within the scope of the study. Bibliometric analysis was used to form the bibliometric networks of correlating publications and to create a visual of the networks (Van Eck \& Waltman, 2017).

\section{Findings}

\subsection{Bibliometric findings}

The total of 168 social studies articles that were published between 2007 and 2020 is illustrated according to the number of articles by year in Figure 1 and to the number of citations in Figure 2. It is seen that 3 of the studies in the field of social studies were published in 2020, 28 in 2019, 18 in 2018, 16 in 2017, 21 in 2016, 11 in 2015, 6 in 2014, 11 in 2013, 15 in 2012, 12 in 2011, 12 in 2010, 5 in 2009,8 in 2008 and 2 in 2007, respectively. The oldest article in the Web of Science database in the field of social studies in Turkey is published in 2007, however, the frequency began to increase in 2013, which is shown in Figure 2. Also, the top three universities where these articles published are Anadolu University ( $\mathrm{f}=18$ ), Marmara University ( $\mathrm{f}=16$ ) and Gazi University ( $\mathrm{f}=13$ ).

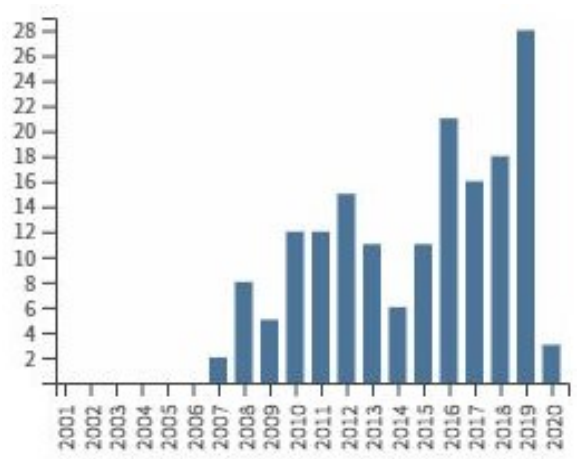

Figure 1. Publications by years.

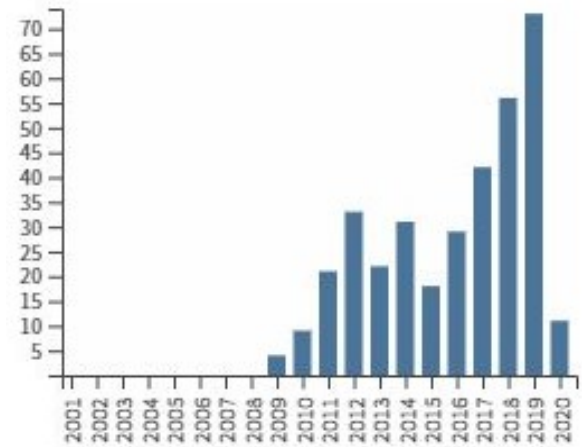

Figure 2. Citations by years.

\subsection{Key words}

VOSviewer program was utilized to reveal the map of the most used keywords in the articles that were written in the field of social studies. The minimum number of repetitions of a keyword was 2 , and as a result, the keywords to be selected automatically was 62 in the VOSviewer program. The map formed for 


\section{Acta Educationis Generalis \\ Volume 11, 2021, Issue 2}

the word network structure is shown in Figure 3. The analysis shows that 12 clusters were converged based on the most used keywords. Table 1 shows the top fourteen most used keywords in the research sample. The annual distribution of the keywords in the articles within the scope of the study is shown in Figure 4.

Table 1

The most used keywords

\begin{tabular}{lcll}
\hline Keyword & $f$ & Keyword & $f$ \\
Social studies & 66 & Achievement & 5 \\
Social studies education & 13 & Education & 5 \\
Citizenship education & 8 & Prospective teachers & 5 \\
Turkey & 7 & Primary school education & 4 \\
Value & 6 & Social studies teacher & 4 \\
Values education & 6 & Metaphor & 4 \\
Teacher training & 6 & Qualitative research & 4 \\
\hline
\end{tabular}

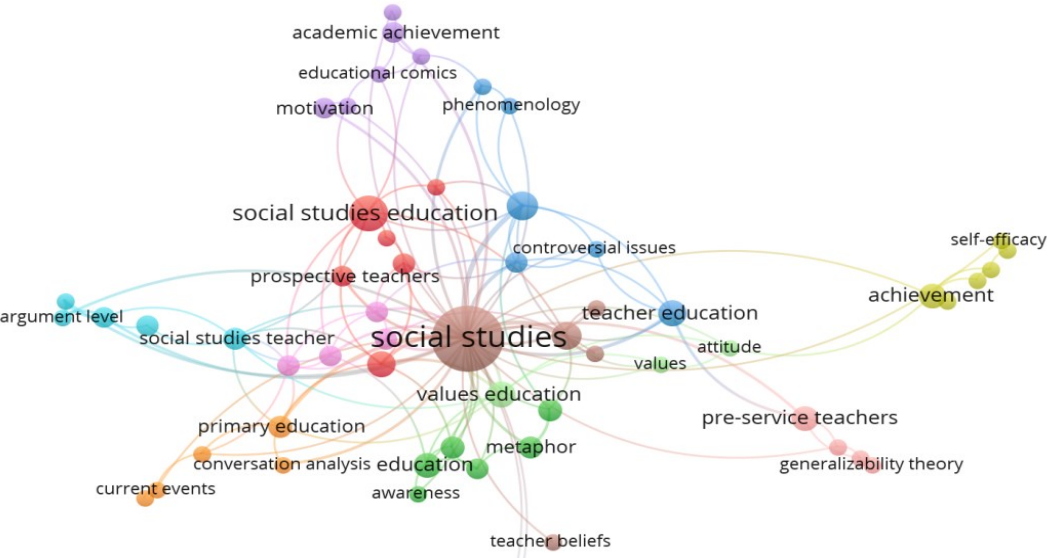

Figure 3. The most-used keywords in social studies articles. 


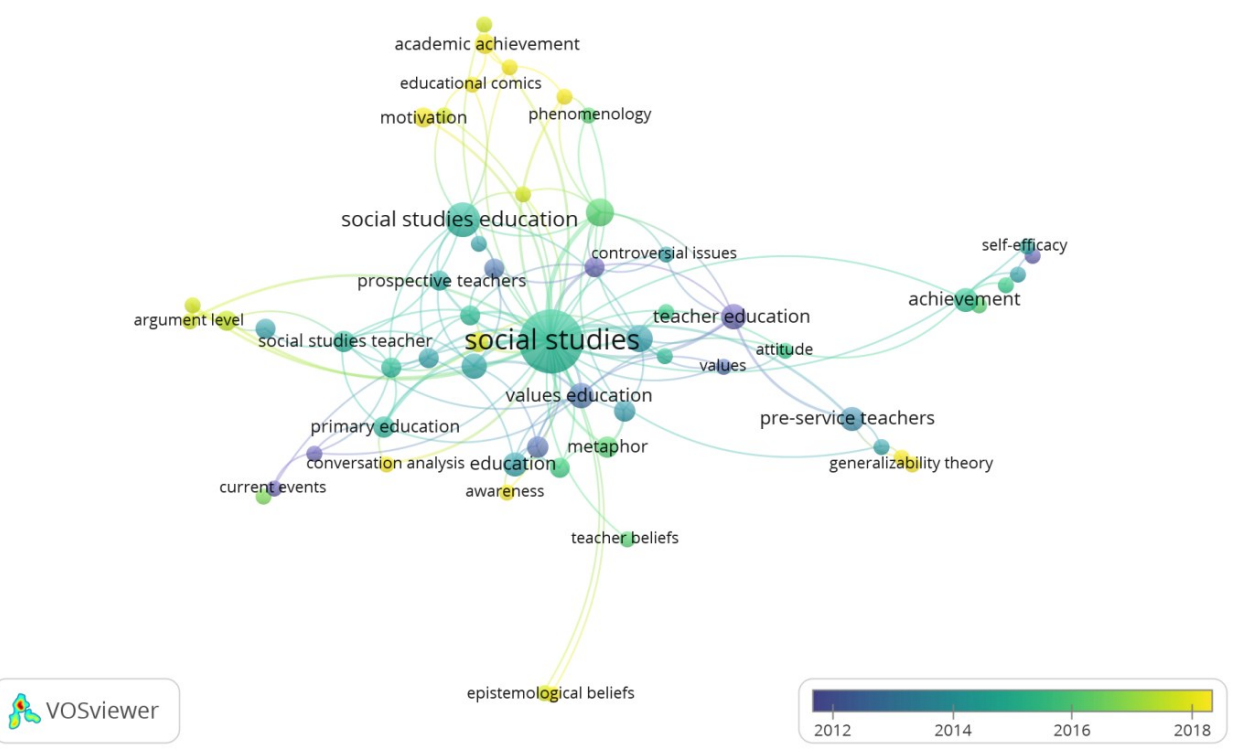

Figure 4. Distribution of the most-used keywords in the articles by years.

\subsection{The most-cited authors}

A co-citation analysis was performed to identify the authors cited most often in the bibliographies of the articles returned from the Web of Science database. A network map of 25 authors receiving at least 13 citations is shown in Figure 5. The network map consists of four clusters, which are colored yellow, red, blue, and green. The most-cited authors within the research sample are: Ali Yildirım (62 citations), Cemil Öztürk (42 citations), John W. Creswell (39 citations), Şener Büyüköztürk (37 citations), Matthew B. Miles (35 citations), Ahmet Doğanay (27 citations), Arife Figen Ersoy (20 citations), and Niyazi Karasar (20 citations).

Then, a citation analysis was conducted for the most-cited authors. The filtering conditions called for an author to have at least two articles cited in at least two citations. Under these conditions, 27 authors were selected. The network map for this analysis appears in Figure 6. The 27 authors selected for the analysis are shown in Table 2. 


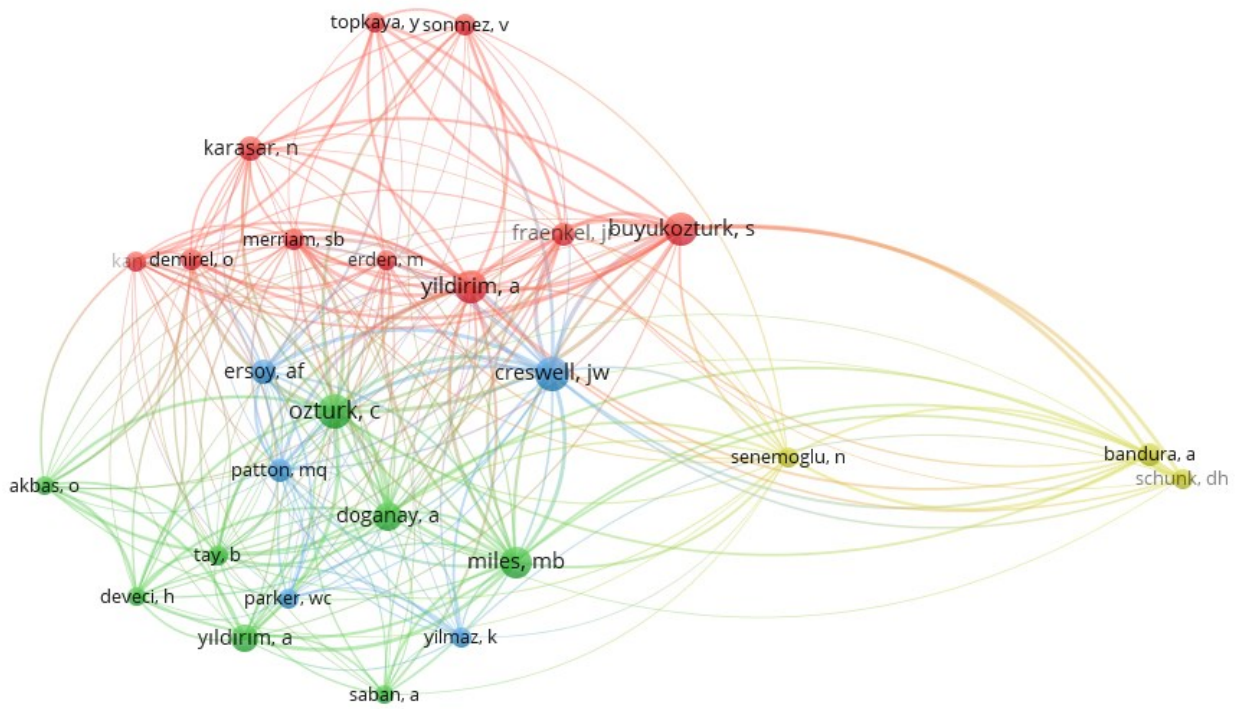

Figure 5. The most-cited authors (co-citation Analysis).

Figure 6. The most-cited authors (citation Analysis).

Table 2

The most-cited authors (citation analysis)

\begin{tabular}{|c|c|c|c|c|c|}
\hline Author & $\frac{\text { Number of }}{\text { articles }}$ & Citations & Author & $\frac{\text { Number of }}{\text { articles }}$ & Citations \\
\hline Ersoy, A. F. & 6 & 30 & Kartal, A. & 2 & 4 \\
\hline Y1lmaz, K. & 5 & 25 & Merey, Z. & 2 & 4 \\
\hline Çengelci, T. & 2 & 10 & Dinç, E. & 4 & 3 \\
\hline Yazıc1, K. & 2 & 10 & Dündar, Ș. & 2 & 3 \\
\hline Deveci, H. & 4 & 8 & Kaymakc1, S. & 3 & 2 \\
\hline Katılmış, A. & 2 & 8 & Kesten, A. & 2 & 2 \\
\hline Tarman, B. & 3 & 8 & Topkaya, Y. & 2 & 2 \\
\hline Öztürk, C. & 4 & 7 & Torun, F. & 2 & 2 \\
\hline Sağlam, H. İ. & 2 & 7 & İlhan, G. O. & 2 & 2 \\
\hline İlter, İ. & 4 & 7 & Aslan, S. & 2 & 2 \\
\hline Tay, B. & 3 & 6 & Meral, E. & 2 & 2 \\
\hline Açıkalın, M. & 2 & 6 & Uslu, S. & 2 & 2 \\
\hline Gökçe, N. & 2 & 6 & Uztemur, S. & 2 & 2 \\
\hline Çalışkan, H. & 2 & 4 & & & \\
\hline
\end{tabular}




\subsection{The most-cited journal (citation and co-citation analysis)}

A citation analysis was applied to the articles. The criteria called for a minimum of five selected articles from a journal, and each article had to have a minimum of one citation. Based on these results, seven journals were returned. The citation network map for these journals is shown in Figure 7. The most-cited journals were Kuram ve Uygulamada Eğitim Bilimleri (76 citations, 33 articles), Eğitim ve Bilim (68 citations, 31 articles), Eurasian Journal of Educational Research (25 citations, 16 articles), Hacettepe Eğitim Fakültesi Dergisi (11 citations, 14 articles), Australian Journal of Teacher Education (6 citations, 5 articles), Journal of Education and Future (5 citations, 9 articles), and Pegem Eğitim ve Öğretim Dergisi (2 citations, 9 articles).

In addition, a co-citation analysis was conducted for the journals. For it, we determined that a journal should have at least 22 citations, and 22 journals were returned. The map formed based on this analysis is shown in Figure 8. The mostcited journals were: The Social Studies (64 co-citations), Journal of Educational Psychology (56 co-citations), Eğitim ve Bilim (53 co-citations), Hacettepe Eğitim Fakültesi Dergisi (51 co-citations), Computers \& Education (45 cocitations), Değerler Eğitimi Dergisi (44 co-citations), and Educational Leadership (37 co-citations).

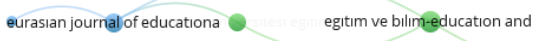

Figure 7. The most-cited journals (citation analysis).

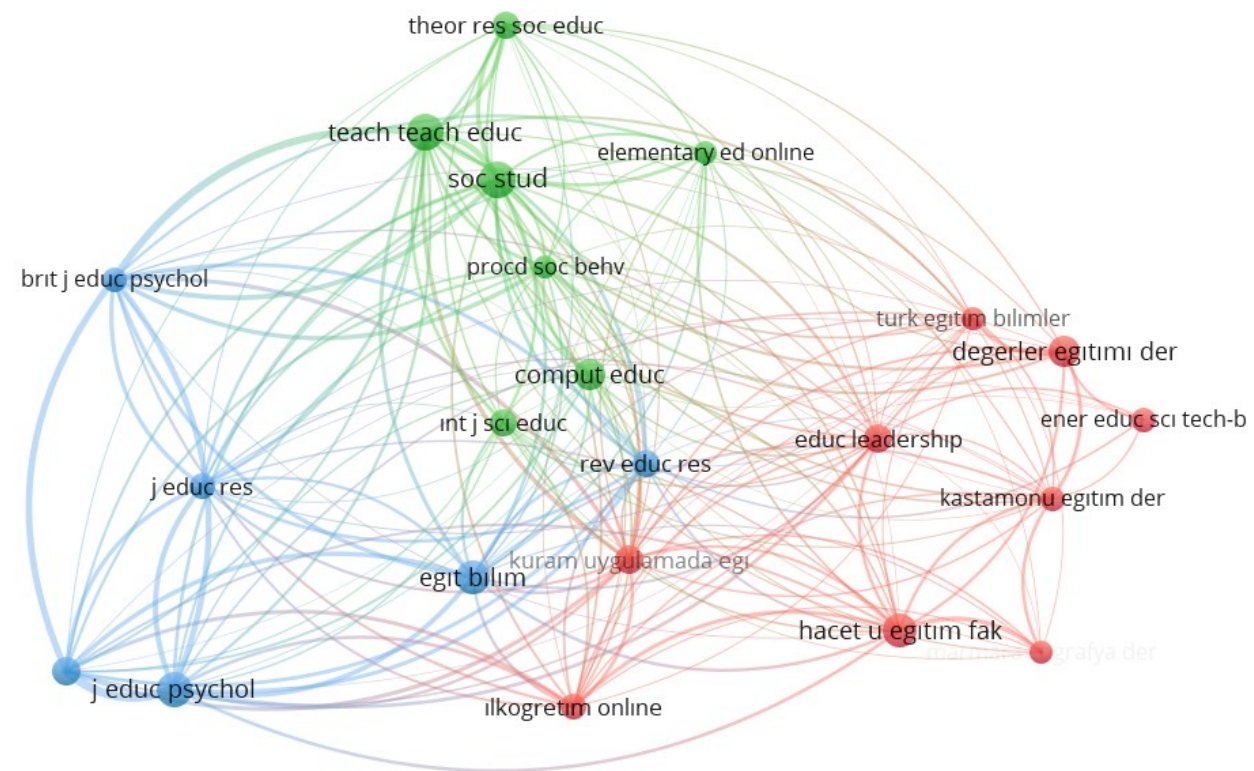

Figure 8 . The most-cited journals (co-citation analysis). 


\section{Acta Educationis Generalis \\ Volume 11, 2021, Issue 2}

\subsection{The most-used words in abstract sections}

The words most often used in the articles' abstracts were analyzed as part of the study, and a map was made depicting them. For this task, the minimum number of repetitions of a word was set to 10; 62 words were returned from the analysis. The map is shown in Figure 9. On the map, three clusters emerged, colored as green, blue, and red. The most frequently used words in the articles' abstracts were: level ( $\mathrm{f}=55)$, Turkey ( $\mathrm{f}=48)$, participant $(\mathrm{f}=46)$, impact $(\mathrm{f}=38)$, interview $(\mathrm{f}=36)$, process $(\mathrm{f}=35)$, program $(\mathrm{f}=35)$, social studies course $(\mathrm{f}=35)$, and scale $(\mathrm{f}=31)$. The distribution of the most used words in the abstracts of the articles by years covered in the study is shown in Figure 10.

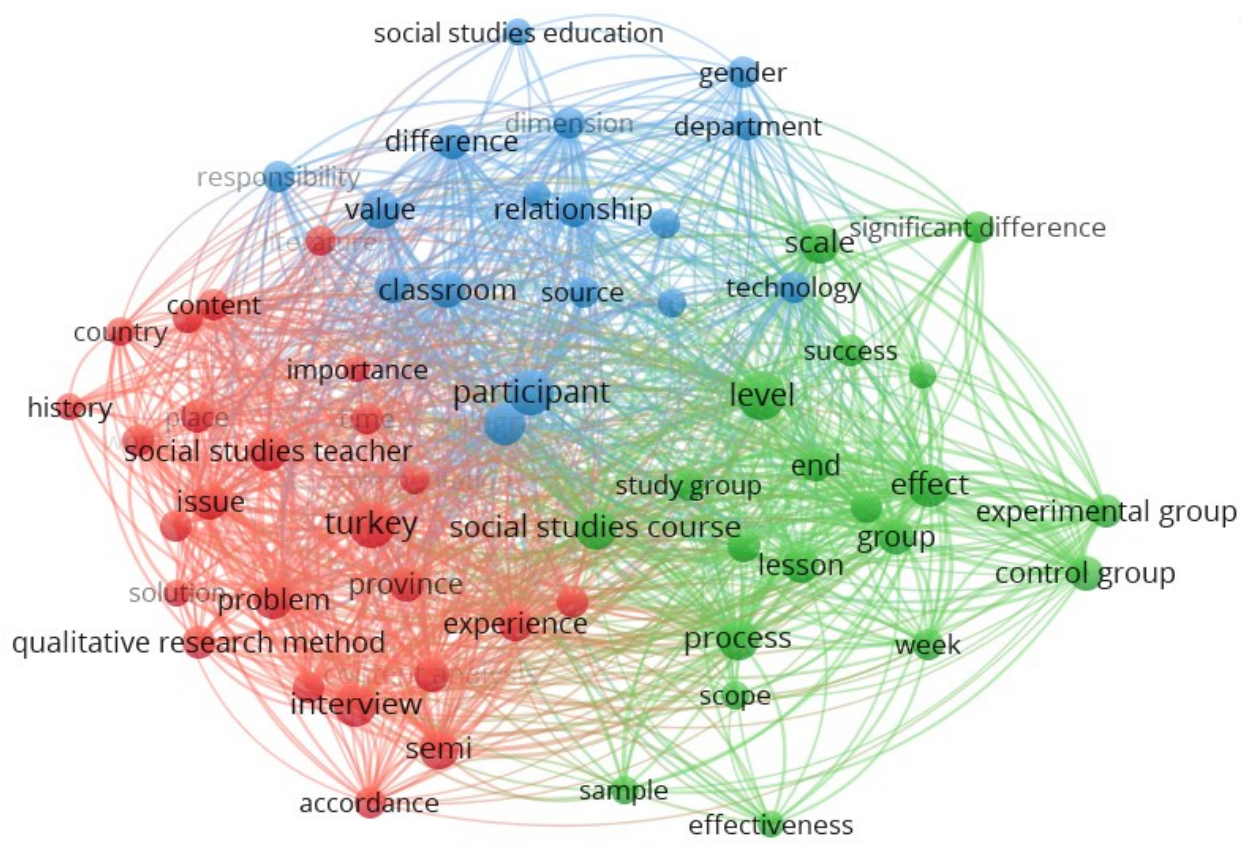

Figure 9. The most-used words in article abstracts. 


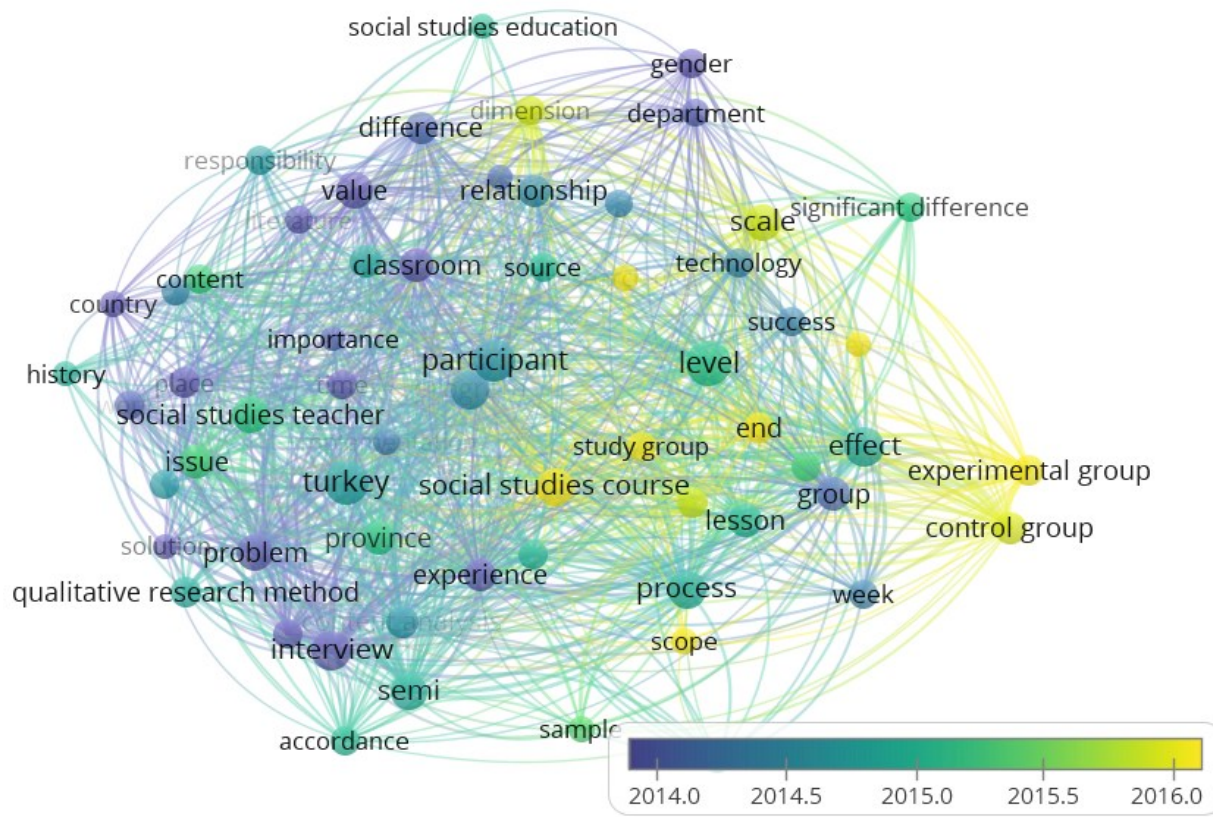

Figure 10. Distribution of the most-used words in article abstracts by years.

\section{Discussion}

This study was conducted to reveal the bibliometric features of the articles in the field of social studies. In this context, a bibliometric analysis was performed on 168 articles. The analysis revealed that the articles were produced mostly at Anadolu, Marmara, and Gazi Universities. When the articles were analyzed by year of publication, we noted that the first was published in 2007, and that article was first cited in 2009. We believe that the reasons are the foundation of the Turkish Social Studies Education, in 1997, and the increase in academic staff with the opening of social studies departments in different cities since 2005 (Tarman et al., 2010). It is also important to note that social studies education has not been practiced for as long in Turkey as other departments have been in operation (Oruç \& Ulusoy, 2008). Finally, the fact that the Web of Science database contained article from only 50 countries in 2003 and 74 countries in 2005, but had grown to 90 countries by 2008, was a factor in this increase rate of research (Clarivate Analytics, 2020). When the numbers of articles were examined, we found that the greatest number of them were published in 2019. The articles' most-used keywords were also analyzed. Keywords are an important theme in bibliometric analysis (Wang \& Chai, 2018). Our results show that the most-used keywords in social studies are "social studies," "social studies education," and "citizenship education." In addition to these words, it can be said that the use of the word value in keywords is due to a lot of publications about value (Čepelová \& Barnová, 2020). The frequency of the keywords' use 
also provides an overview of research trends in the field (Huai \& Chai, 2016). In addition, since the keywords help indexes and search engines to find relevant articles, choosing the right keyword leads to more citations of a given study. The keywords used should be specific to both the content of the article and its area or sub-domains (Springer, 2020).

The authors who received the most citations were Ali Yıldırım, Cemil Öztürk, John W. Creswell, Şener Büyüköztürk, Matthew B. Miles, Ahmet Doğanay, and Arife Figen Ersoy, based on our co-citation analysis. The most-cited authors were Arife Figen Ersoy, Kaya Yılmaz, Tuba Çengelci, Kubilay Yazıcı, Handan Deveci, and Ahmet Katılmış, according to the citation analysis. The most-cited journals were Kuram ve Uygulamada Eğitim Bilimleri, Eğitim ve Bilim, and the Eurasian Journal of Educational Research, in the citation analysis, and the mostcited journals in the co-citation analysis were The Social Studies, Journal of Educational Psychology, and Eğitim ve Bilim. The Turkey-based journals among these have good qualification indexes and are regarded as the best journals in Turkey, given the indexes in which they are included. Most of the journals noted here are not specific to social studies, but instead are general educational journals. Lv et al. (2011) highlighted that it is important to identify the most-cited studies in a given field.

\section{Limitations}

The only articles examined in this study are those that appear in the Web of Science database and which were conducted in Turkey. These can be considered limitations of the study.

\section{Conclusion}

In the light of the results of this study, several suggestions can be presented:

The articles retrieved in the study were selected from the Web of Science database, and bibliometric analyses were performed. Thorough analyses can also be performed using different databases and variables.

Considering that the most-cited authors according to the study's results are included in many of the bibliographies of studies related to this field, examining these authors' works may be useful for interested scholars.

A majority of the journals included in this study were general education journals. A future study might consider only journals that publish social studies articles. The majority of the most-cited journals in this study are based in Turkey. Researchers carrying out similar studies might opt to examine journals with a different country of origin.

The recently used keywords related to the field of social studies can be examined to plan future studies. For example, trends can be determined by comparing recently used keywords with relevant studies in other countries. 


\section{Acta Educationis Generalis \\ Volume 11, 2021, Issue 2}

For future studies' meta-analyses, a meta-synthesis or compilation of social studies articles would be suitable. Such studies are important, in terms of providing a general perspective for interested scholars.

\section{References}

Ay-Selanik, T., \& Deveci, H. (2016). Ways of using internet by classroom teachers in social studies course. Journal of Education and Future, 9, 31-48.

Akpınar, M., \& Kaymakcı, S. (2012). Ülkemizde sosyal bilgiler öğretiminin genel amaçlarına karşılaștırmalı bir bakıș. Kastamonu Education Journal, 20(2), 605-626.

Čepelová, S., \& Barnová, S. (2020). Quality of life and value orientation of university students in middle-adulthood. Acta Educationis Generalis, 10(1), 68-80. https://doi.org/10.2478/atd2020-0005

Clarivate Analytics. (2020). Who we are and how we got here: A quick history of Web of Knowledge. Retrieved from http://wokinfo.com/about/whoweare/

Deveci, H. (2005). Sosyal bilgiler dersinde gazete kullanımı. TOJET: The Turkish Online Journal of Educational Technology, 4(3), 159-166.

Dilek, A., Baysan, S., \& Öztürk, A. A. (2018). Türkiye'de sosyal bilgiler eğitimi üzerine yapılan yüksek lisans tezleri: Bir içerik analizi çalışması. Turkish Journal of Social Research, 22(2), 581-602.

Doğanay, A. (2008). Çağdaş sosyal bilgiler anlayışı 1şı̆̆ında yeni sosyal bilgiler programının değerlendirilmesi. Çukurova Üniversitesi Sosyal Bilimler Enstitüsü Dergisi, 17(2), 77-96.

Eryılmaz, Ö., \& Çengelci-Köse, T. (2018). Sosyal bilgilerde edebi ürünler ve değerler eğitimi: Küçük Prens örneği. Batı Anadolu Ĕ̆itim Bilimleri Dergisi, 9(1), 65-79

Garwood, J., McKenna, J., Roberts, G., Ciullo, S., \& Shin, M. (2019). Social studies content knowledge interventions for students with emotional and behavioral disorders: A metaanalysis. Behavior Modification, 1-30. https://doi.org/10.1177/0145445519834622

Görmez, E. (2018). The comparison of the achievements in the primary school social studies program and the college, career and civil life (C3) framework program. Hacettepe University Journal of Education, 33(3), 565-580. https://doi.org/10.16986/HUJE.2017032925

Güleç, S., \& Hüdavendigar, M. N. (2020). Sosyal Bilgiler eğitimi alanında okuryazarlık becerisi başlığında yapılan lisansüstü tezlerin incelenmesi. Uluslararası İnsan ve Sanat Araştırmaları Dergisi, 3(3), 24-36.

Gürlen, E., Özdiyar, Ö., \& Şen, Z. (2018). Üstün yeteneklilere yönelik akademik çalışmaların sosyal ağ analizi. Ĕgitim ve Bilim, 44(197), 185-208. https://doi.org/10.15390/EB.2018.7735

Huai, C., \& Chai, L. (2016). A bibliometric analysis on the performance and underlying dynamic patterns of water security research. Scientometrics, 108(3), 1531-1551. https://doi.org/ 10.1007/s11192-016-2019-x

Lv, P. H., Wang, G. F., Wan, Y., Liu, J., Liu, Q., \& Ma, F. C. (2011). Bibliometric trend analysis on global graphene research. Scientometrics, 88(2), 399-419.

National Council for the Social Studies. (2018). About National Council for the Social Studies. Retrieved from https://www.socialstudies.org/about

Oruç, Ş., \& Ulusoy, K. (2008). Sosyal bilgiler alanında yapılan tez çalışmaları. Ahmet Keleşoğlu Eğitim Fakültesi Dergisi, 26, 121-132.

Öztürk, C. (2009). Sosyal bilgiler: Toplumsal yaşama disiplinlerarası bir bakış. C. Öztürk (Ed.) Sosyal bilgiler öğretimi demokratik vatandaşlık eğitimi içinde (pp. 1-31). Ankara: Pegem A Yayıncilik.

Seefeldt, C., Castle, S., \& Falconer, R. C. (2014). Social studies for the preschool-primary child ( $9^{\text {th }}$ edition). New Jersey: Pearson. 


\section{Acta Educationis Generalis \\ Volume 11, 2021, Issue 2}

Shen, C., \& Ho, J. (2020). Technology-enhanced learning in higher education: A bibliometric analysis with latent semantic approach. Computers in Human Behavior, 104, 106177. https://doi.org/10.1016/j.chb.2019.106177

Springer. (2020). Title, abstract and keywords. Retrieved from https://www.springer.com/ gp/authors-editors/authorandreviewertutorials/writing-a-journal-manuscript/title-abstract-and keywords/10285522

Şahin, M., Göğebakan-Yıldız, D., \& Duman, R. (2011). Türkiye'deki sosyal bilgiler eğitimi tezleri üzerine bir değerlendirme, Journal of Social Studies Education Research, 2(2), 96-121.

Şahin, M., Şahin, S., \& Göğebakan-Yıldız, D. (2016). Sosyal bilgiler eğitimi programı ve dünya vatandaşlığı: öğretmen adaylarının perspektifinden. Hacettepe Üniversitesi Ĕ̈itim Fakültesi Dergisi, 31(2). 369-390. https://doi.org/10.16986/HUJE.2016015386

Tarman, B., Acun, İ., \& Yüksel, Z. (2010). Sosyal bilgiler eğitimi alanındaki tezlerin değerlendirilmesi. Gaziantep Üniversitesi Sosyal Bilimler Dergisi, 9(3), 725-746. Retrieved from http://dergipark.org.tr/tr/pub/jss/issue/ 24245/257053

Tay, B., \& Akyürek-Tay, B. (2006). Sosyal bilgiler dersine yönelik tutumun erişiye etkisi. Türk Eğitim Bilimleri Dergisi, 4(1), 73-84.

Türk, N., \& Nalçacı, A. (2011). İlköğretim beşinci sınıf öğrencilerinin sosyal bilgiler programında verilen değerleri edinme düzeyleri (Erzincan Örneği). Erzincan Üniversitesi Eğitim Fakültesi Dergisi, 13(2), 39-56.

Van Eck, N. J., \& Waltman, L. (2010). Software survey: VOSviewer, a computer program for bibliometric mapping. Scientometrics, 84(2), 523-538.

Van Eck, N. J., \& Waltman, L. (2017). Citation-based clustering of publications using CitNetExplorer and VOSviewer. Scientometrics, 111(2), 1053-1070.

Wang, M., \& Chai, L. (2018). Three new bibliometric indicators/approaches derived from keyword analysis. Scientometrics, 116(2), 721-750. https://doi.org/10.1007/s11192-0182768-9

Yaşar, Ş., Çengelci-Köse, T., Göz, N., \& Bayır, Ö. G. (2015). Sosyal bilgiler dersinde öğrenci merkezli öğretme-öğrenme süreçlerinin etkililiği: Bir meta analiz çalışması. Anadolu Üniversitesi Ĕgitim Bilimleri Enstitüsü Dergisi, 5(1), 38-56. 